Z. Klin. Chem. Klin. Biochem.

13. Jg. 1975 , S. $461-464$

\title{
Effect of Bilirubin on Stored Red Blood Cells
}

\author{
By Chr. Petrich, U. Göbel and U. Delvos
}

Universitäts-Kinderklinik Düsseldorf

(Eingegangen am 17. Februar/3. Juni 1975)

Summary: Bilirubin may cause haemolysis of red cells, especially in the presence of light. The possible dependence of this effect on the metabolic state of the cells has been investigated. For this purpose erythrocytes were stored up to five days to deplete the concentration of ATP. Every day a constant amount of bilirubin was added to the cells. On third day of storage bilirubin induced haemolysis, which was aggravated rapidly during further storage. Bilirubininduced haemolysis could be reduced after increasing the ATP levels by incubation of the red cells with inosine.

\section{Wirkung von Bilirubin auf gelagerte Erythrocyten}

Zusammenfassung: Bilirubin kann besonders bei gleichzeitiger Einwirkung von Licht zu einer Hämolyse von Erythrocyten führen. Bei diesem Vorgang ist es jedoch unbekannt, ob er in Beziehung zu der jeweiligen Stoffwechsellage der Erythrocyten steht. Es wurde deshalb Blut fünf Tage lang gelagert und auf diese Weise in Abhängigkeit von der Lagerungsdauer die ATP-Konzentration in den Erythrocyten verringert. Die Erythrocyten wurden nun täglich mit einer konstanten Bilirubinmenge versetzt. Vom dritten Lagerungstag an kam es nach Zugabe von Bilirubin zu einer Hämolyse, die sich im Verlauf der weiteren Lagerung rasch verstärkte. Wurden die gelagerten Erythrocyten mit Inosin inkubiert, kam es parallel mit einem Anstieg der ATP-Konzentration zu einem Rückgang der durch Bilirubin induzierten Hämolyse.

\section{Introduction}

Unconjugated bilirubin exerts certain toxic effects on cell metabolism. These concern oxidative phosphorylation in liver mitochondria $(1,2)$, and in red cells the concentration of ATP (3), ATPase activity (4), and glucose consumption (3). The toxic effects of bilirubin on erythrocytes can be enhanced by light, which may induce haemolysis $(4,5,6)$. Some investigators have found that bilirubin also induces haemolysis in the dark $(4,5)$.

In this study we examine whether the effects of bilirubin on the red cells are related to the metabolic situation of the erythrocytes. For this purpose, red cells were stored up to five days and in this way artificially depleted of ATP. Every day the uptake of bilirubin by the red cells was measured until haemolysis was observed and haemolysis itself was determined. Furthermore the stored erythrocytes were incubated every day with inosine before adding them to bilirubin. Inosine is able to increase the ATP and 2, 3-diphosphoglycerate concentration in stored erythrocytes $(7,8)$. If inosine is used in combination with pyruvate this effect is even more pronounced (9). In this way the effects of storage are partially reversible.

\section{Methods}

Blood was obtained from healthy adult volunteers. $9 \mathrm{ml}$ of blood were mixed with $1 \mathrm{ml}$ of sodium citrate and the blood was stored without further additives in the dark at room temperature.

Every 24 hours an aliquot of the blood was incubated with inosine as follows: $1 \mathrm{ml}$ of blood was added to $4 \mathrm{ml}$ of a solution, which contained equal parts of Ringer's solution and phosphate buffer $0.1 \mathrm{~mol} / 1, \mathrm{pH}$ 7.4. The incubation medium contained inosine and pyruvate in a final concentration of $10 \mathrm{mmol} / 1$ and $5 \mathrm{mmol} / 1$, respectively (9). Incubation was performed at $37^{\circ} \mathrm{C}$ for 2 hours and 60 oscillations per minute in the dark. At the end of the incubation time the blood was washed three times with triethanolamine $\mathrm{HCl} 0.1 \mathrm{~mol} / 1$, pH 8.0.

A blank sample was prepared exactly in the same way, but was washed with triethanolamine immediately after addition of inosine. In both samples ATP was determined using the phosphoglycerate kinase method (10). Now $5 \mathrm{mg}$ bilirubin p. a. from Merck AG, Germany, were dissolved in $0.5 \mathrm{ml}$ of sodium hydroxide $0.2 \mathrm{~mol} / \mathrm{l}$ and triethanolamine $\mathrm{HCl}$ $0.1 \mathrm{~mol} / \mathrm{l}, \mathrm{pH} 8,0$ was added up to $100 \mathrm{ml}$.

$0.5 \mathrm{ml}$ of the incubated and of the corresponding non-incubated blood sample were added to $0.5 \mathrm{ml}$ of the bilirubin solution and gently mixed. In these samples the haematocrit and the haemoglobin concentration were determined. After 10 minutes in the dark the reagent tube was centrifuged for one minute and the haemoglobin concentration was determined in the supernatant. Bilirubin was determined in the supernatant under the condition that no haemolysis could be 
found. Bilirubin uptake by the cells was calculated from the initial bilirubin concentration in the sample and the final bilirubin concentration in the supernatant. The initial bilirubin concentration was obtained from the following equation: bilirubin initial $=$ bilirubin in the stock solution $(\mu \mathrm{mol}) / 200-\mathrm{Hkt}$ sample $(\mathrm{ml})$. Bilirubin uptake by the red cells is expressed as the decrease from the initial bilirubin concentration in per cent and per $\mathrm{Hb}$ extinction 0.100 . Bilirubin-induced haemolysis is expressed as the haemolyzed amount of haemoglobin in per cent of the total haemoglobin content. Bilirubin concentrations were determined according to Jendrassik \& Gróf (11). For determination of haemoly sis $0.2 \mathrm{ml}$ samples were used in the cyanmethhaemoglobin method.

\section{Results}

\section{ATP decrease during storage}

In figure 1 the decrease in ATP content of the red cells for every day of storage is given. The stored blood was investigated for spontaneous haemolysis every day, which could not be found during the period of investigation. The overall increase of ATP during the 2 hours of incubation with inosine was from $348 \pm$ 126 up to $522 \pm 200 \mu \mathrm{mol} / 1$ of blood $\left(t_{\text {paired }}=4.5\right.$, $\mathrm{p}<0.001)$.

\section{Bilirubin uptake of the red cells}

The mean value of bilirubin uptake before incubation with inosine was found to be $67.5 \pm 8.2$ per cent, after incubation with inosine $61.0 \pm 7.8$ per cent. The decrease in bilirubin uptake could be found in every of 20 experiments $\left(\mathrm{t}_{\text {paired }}=-5.0, \mathrm{p}<0.001\right)$.

\section{Bilirubin-induced haemolysis}

Under our conditions of investigation bilirubin induced haemolysis of the erythrocytes on third day of storage, and this effect aggravated rapidly during further storage (fig. 2). Incubation of the stored blood with inosine resulted in a decrease of haemolysis in each of $18 \mathrm{ex}$ periments. In table 1 the statistical analysis of these results is given.

Bilirubin-induced haemolysis and ATP concentration

In figure 3 the ATP concentration and the degree of haemolysis before incubation with inosine are shown.

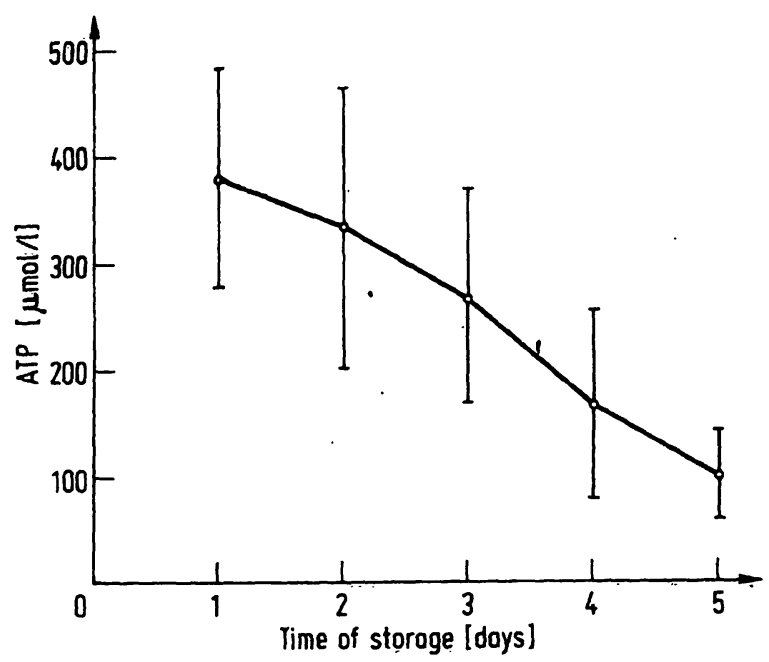

Fig. 1. ATP depletion of red cells during storage.

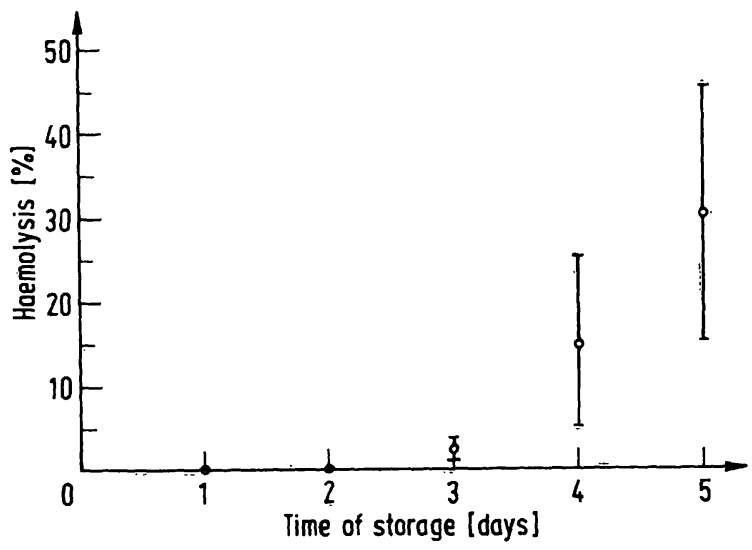

Fig. 2. Haemolysis observed after addition of bilirubin to the stored red cells on different days of storage.

In figure 4 all values from figure 3 are given and additionally the ATP concentrations and the observed haemolysis after incubation with inosine. The regression line is described by the equation $y=27 \mathrm{e}^{-0.15 x}$ $(r=0.603, n=36, p<0.001)$.

Tab. 1. Bilirubin-induced haemolysis of red cells and ATP concentration before and after incubation of the red cells with inosine

\begin{tabular}{|c|c|c|c|c|}
\hline & $\begin{array}{l}\text { haemolyșis } \\
\text { initial } \\
\text { [\%] }\end{array}$ & $\begin{array}{l}\text { haemolysis } \\
\text { after inosine } \\
{[\%]}\end{array}$ & $\begin{array}{l}\text { ATP } \\
\text { initial } \\
{[\mu \mathrm{mol} / \mathrm{l}]}\end{array}$ & $\begin{array}{l}\text { ATP } \\
\text { after inosine } \\
{[\mu \mathrm{mol} / 1]}\end{array}$ \\
\hline $\begin{array}{l}\text { median } \\
95 \text { per cent confidence level of the median } \\
\text { range }\end{array}$ & $\begin{array}{l}4.65 \\
2.1 \\
51.1\end{array}$ & $\begin{array}{l}1.3 \\
0.6-3.7 \\
17.6\end{array}$ & $\begin{array}{l}185 \\
1204^{-281}\end{array}$ & $\begin{array}{l}351 \\
226 \\
566^{-533}\end{array}$ \\
\hline significance of the difference & $\mathrm{p}<0.001$ & & $p<0.001$ & \\
\hline
\end{tabular}




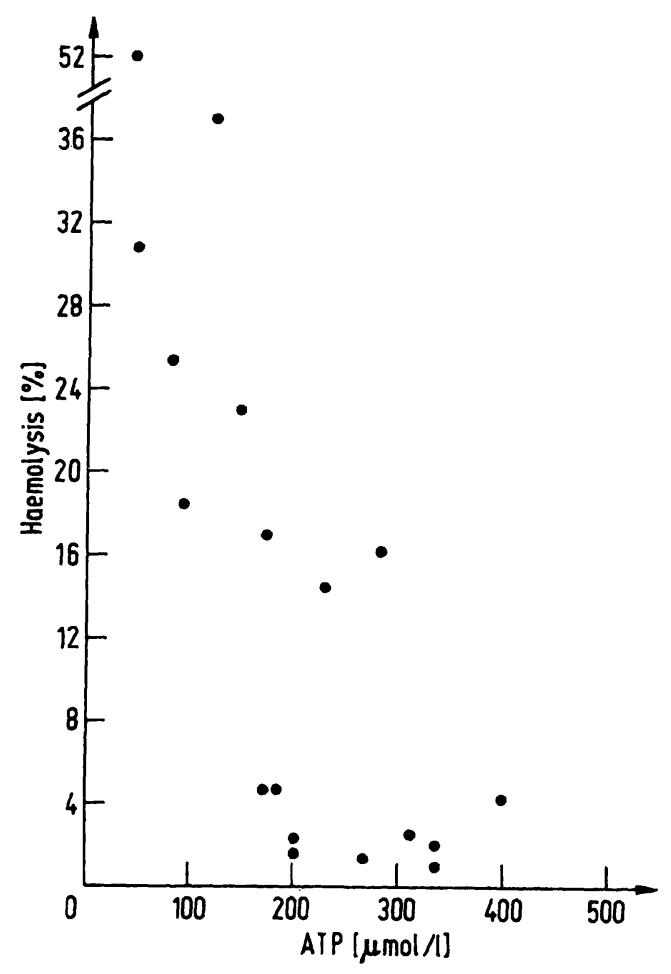

Fig. 3. ATP concentration and bilirubin-induced haemoylsis before incubation of the blood with inosine.

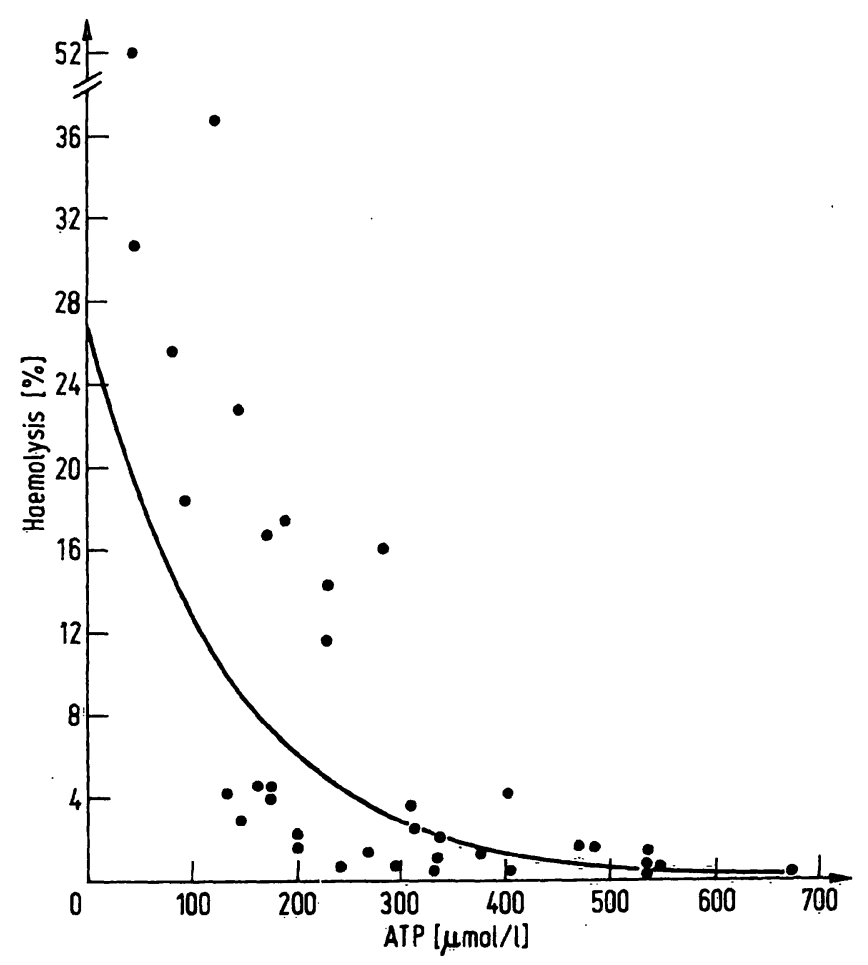

Fig. 4. ATP concentration and bilirubin-induced haemolysis before and after incubation of the blood with inosine. ATP and haemolysis show a significant exponential correlation $(\mathrm{r}=0.603, \mathrm{n}=36, \mathrm{p}<0.001)$.

\section{Discussion}

The uptake of bilirubin by the red cells has already been the subject of several investigations $(12-15)$. The amount of bilirubin, however, which is taken up, does not seem to be unvariable, because it was found to be reduced after incubation of the red cells with inosine. As the main effect of inosine concerns the level of organic phosphates within the red cell, further investigations must show, whether a causal relationship exists.

First observations regarding the haemolytic effect of bilirubin without additional influence of light were made by Odell (4) and Blackburn (5). Our results show that on the third day of storage under our experimental conditions bilirubin induced the haemolysis of red cells without the additional influence of light. This effect is nearly reversible by an artificial increase of the ATP concentration. On the fourth and fifth day of storage haemolysis, after the addition of bilirubin, increases rapidly. In every case, haemolysis can be diminished by about 60 per cent by a preceding incubation with inosine. The significant correlation between ATP and bilirubin-induced haemolysis suggests an ATP-dependent system, which protects the red cell from the haemolytic effect of bilinubin.

It is of great interest whether unconjugated bilirubin may also cause haemolysis in man. The final concentrations used in our experiments were about $50 \mu \mathrm{mol} / 1$. In newborns with hyperbilirubinaemia, markedly higher levels can be found, although a high portion will be bound to albumin (16). However, even at low bilirubin concentrations a steady state can be found between erythrocytes and albumin, resulting in a binding of bilirubin to the erythrocytes at low concentrations (12).

The decrease of haemolysis after incubation of ATP. depleted red blood cells with inosine raises the question of whether ATP-deficient cells generally are more sensitive to the toxic effects of bilirubin. In connection with this possibility it appears of interest that Schenker could demonstrate an increased bilirubin uptake in ATP-deficient nerve cells (17).

In an earlier investigation we demonstrated lowered 2, 3-diphosphoglycerate levels, but normal ATP concentrations in the blood of newborns with transitory hyperbilirubinaemia $(18,19)$. This can be explained by a restoration of the stored ATP in vivo from 2, 3-diphosphoglycerate.

\section{Acknowledgement}

We wish to thank Prof. Dr. S. Hollmann, Institut für Physiologische Chemie I der Universität Düsseldorf, for reading the manuscript. 


\section{References}

1. Zetterström, R. \& Ernster, L. (1956), Nature (London) 178, 1335-1337.

2. Diamond, I. \& Schmid, R. (1967), Science $155,1288-$ 1289.

3. Cheung, W. H., Sawitsky, A. \& Isenberg, H. D. (1966), Transfusion 6, 475-486.

4. Odell, G. B., Brown, R. S. \& Kopelman, A. E. (1972), J. Pediat. 81, 473-483.

5. Blackburn, M. G., Orzalesi, M. M. \& Pigram, P. (1972), Biol. Neonate 21, 35-43.

6. Saeki, K. (1932), Jap. J. Gastroenterol. 4, 153-165.

7. Akerblom, O., de Verdier, C. H., Garby, L. \& Högman, C. (1968), Scand. J. Clin. Invest. 21, 245-248.

8. Akerblom, O., de Verdier, C. H., Erikson, A., Garby, L. \& Högman, C. (1967), 8th Berliner Symposium on Structure and Function of Erythrocytes, Berlin.

9. Oski, F. A., Traevis, S. F., Miller, L. D., Delivoria-Papadopoulos, M. \& Cannon, E. (1971), Blood 37, 52-58.
10. Jaworek, D., Gruber, W. \& Bergmeyer, H. U. (1970), in Methoden der enzymatischen Analyse, (Bergmeyer, H. U. ed.) 2. Aufl. p. 2020. Verlag Chemie, Weinheim/Bergstr.

11. Jendrassik, L. \& Gróf, P. (1938) Biochem. Z. 297, 81-89.

12. Barnhart, J. L. \& Clarenburg, R. (1973) Proc. Soc. Exp. Biol. Med. 142, 1101-1103.

13. Bratlid, D. (1972) Scand. J: Clin. Lab. Invest. 29, 91-97.

14. Oski, F. A. \& Naiman, J. L. (1963) Pediatrics 63, 10341037.

15. Watson, D. (1962) Clin. Chim. Acta 7, 733-734.

16. Nakamura, H. \& Lardinois, R. (1972) Biol. Neonate 21, 400-417.

17. Schenker, S., McCandless, D. W. \& Wittgenstein, E. (1964) J. Lab. Clin. Med. 64, 1002-1003.

18. Petrich, C., Gempp-Friedrich, W. \& Göbel, U. (1973) Acta Paediat. Scand. 62, 596-600.

19. Petrich, C. \& Göbel, U. (1974), Z. Kinderheilk. 117, 121126.

Dr. C. Petrich Universitäts-Kinderklinik D-4 Düsseldorf Moorenstraße 5 